\title{
Acute hypothalamic administration of L-arginine increases feed intake in rats
}

\author{
Administração hipotalâmica aguda de L-arginina \\ aumenta a ingestão alimentar em ratos
}

Carlos Ricardo Maneck MALFATTI ${ }^{1}$

Luiz Augusto da SILVA

Ricardo Aparecido PEREIRA ${ }^{1}$

Renan Garcia MICHEL' ${ }^{1}$

André Luiz SNAK ${ }^{1}$

Fabio Seidel dos SANTOS 2

A B S T R A C T

\section{Objective}

This study investigated the chronic (oral) and acute (hypothalamic infusion) effects of L-arginine supplementation on feed intake, body composition, and behavioral changes in rats.

\section{Methods}

Twenty rats were divided into two groups treated orally for 60 days; one group received L-arginine (1 g/kg body weight) and one group received saline ( $1 \mathrm{~mL} / \mathrm{NaCl} 0.9 \%)$. Daily consumption of water and food were evaluated, and weight monitored. After the oral treatment, the rats underwent stereotactic biopsy and a group was injected with $2 \mu \mathrm{L}$ of L-arginine $(0.5 \mathrm{mM})$ and another received an injection of saline $(0.9 \% \mathrm{NaCl})$, in the hypothalamic route, through micro infusion. Immediately after micro infusion, the animal behavior was evaluated through tests in the open field. Food and water consumption were evaluated at 12 and 24 hours after the micro infusion. Daily water consumption and weight gain evolution were evaluated. At the end of treatments, rats were euthanized and blood was collected for glucose, glycerol, and cholesterol evaluation, and histological analysis of vital organs.

\section{Results}

Oral supplementation with L-arginine increased water intake $(11 \%, p<0.05)$ and promoted weight gain $(3 \%$, $p<0.05)$. However, hypothalamic infusion promoted a significant increase in chow intake $(30 \%, p<0.05)$ after 24 hours of L-arginine administration.

\footnotetext{
${ }^{1}$ Universidade Estadual do Centro-Oeste, Setor de Ciências da Saúde, Programa de Pós-Graduação em Ciências Farmacêuticas. R. Simeão Camargo Varela de Sá, 3, 85040-080, Guarapuava, PR, Brasil. Correspondência para/Correspondence to: CRM MALFATTI. E-mail: <crmalfatti@gmail.com>.

2 Universidade Estadual do Centro-Oeste, Setor de Ciências Agrárias e Ambientais, Programa de Pós-Graduação em Biologia Evolutiva. Guarapuava, PR, Brasil.
} 


\section{Conclusion}

Chronic oral treatment with L-arginine was not effective on appetite modulation; however, an effect was observed when L-arginine was administered directly into the hypothalamus, suggesting a central regulation on appetite through nNOS sensitization. Chronic use of L-arginine did not cause substantial changes in anthropometric, biochemical, behavioral, or histological variables.

Keywords: Central nervous system. Eating. Feeding behavior.

\section{R E S U M O}

\section{Objetivo}

Este estudo investigou os efeitos da suplementação crônica (oral) e aguda (infusão no hipotálamo) com L-arginina sobre a saciedade, composição corporal e mudanças comportamentais em ratos.

\section{Métodos}

Vinte ratos foram divididos em dois grupos e tratados por via oral durante 60 dias; um grupo recebeu uma dose de L-arginina (1 $\mathrm{g} / \mathrm{kg}$ de peso corporal), outro grupo recebeu uma dose de solução salina (1 $\mathrm{mL} / \mathrm{NaCl}$ $0.9 \%)$. O consumo diário de água e comida e a evolução do ganho de peso foram avaliados. Após o tratamento por via oral, os ratos foram submetidos à estereotaxia: um grupo recebeu uma injeção com $2 \mu$ l de L-Arginina (0.5 mM) e outro recebeu uma injeção de solução salina ( $\mathrm{NaCl}$ 0,9\%), no hipotálamo, através de microinfusão. Imediatamente após a microinfusão, foi avaliado o comportamento dos animais através do teste em campo aberto. O consumo de água e de comida foi avaliado nas 12 e 24 horas seguintes à microinfusão. No final dos tratamentos, os ratos foram eutanasiados para coleta de amostras para dosagem de glicose, glicerol e colesterol, além da análise histológica dos órgãos.

\section{Resultados}

A suplementação oral com L-arginina promoveu aumento do consumo de água $(11 \%, p<0,05)$ e ganho de peso $(3 \%, p<0,05)$. Além disso, a infusão hipotalâmica promoveu um aumento significativo do consumo alimentar $(30 \%, p<0,05)$ após 24 horas da administração de L-arginina.

\section{Conclusão}

O tratamento oral crônico com L-arginina não obteve efeitos na modulação do apetite. No entanto, ocorreu aumento da ingestão de alimento quando a L-arginina foi administrada diretamente no hipotálamo, sugerindo que exista uma estimulação do apetite através da sensibilização da nNOS nessa região. O uso crônico de L-arginina não causou mudanças substanciais nos dados antropométricos, bioquímicos, comportamentais ou histológicos.

Palavras-chave: Sistema nervoso central. Ingestão de alimentos. Comportamento alimentar.

\section{INTRODUCTION}

Over the years, the role of Nitric Oxide (NO) has been correlated with multiple functions in the Central Nervous System (CNS) and many pathological dysfunctions such as cognitive function (maintenance of synaptic plasticity), sleep control, body temperature (thermogenesis), influence on the neural control of digestive actions and satiety behaviors (signaling hormones and appetite modulating factors), heart diseases (hypertension and coronary disease), appetite control, and behavioral disorders (obsessive compulsive disorder) ${ }^{1-3}$. In the peripheral nervous system, NO has demonstrated non-adrenergic and non-cholinergic regulation of the smooth muscles in the corpus cavernosum and gastrointestinal tract (non-adrenergic non-cholinergic relaxation of the smooth muscle in the corpus cavernosum and gastrointestinal tract $)^{1}$. NO is synthesized from L-arginine, which is a semi-essential amino acid that can act biologically on four enzymes: arginine decarboxylase, glycine amidinotransferase, arginases, and Nitric Oxide Synthases (NOS) ${ }^{4}$ Its most studied metabolic destination is in the synthesis of NO. Nitric oxide is a gaseous, small, and simple molecule that has raised the interest of researchers in recent decades because of its 
important functions in the human body such as its potential role as a physiological modulator of food intake ${ }^{1,2}$.

Food intake is controlled by complex neural systems that act receiving signs from the digestive system, passing through the adipose tissue, and reaching the $\mathrm{CNS}^{5}$. The hypothalamus is considered one of the main regions of the CNS that is directly related to appetite and the various hormonal and neural mechanisms by which the brain is informed about the availability of ingested, stored, and consumed nutrients ${ }^{6-8}$. Food control mechanisms are controlled by the hypothalamus function through the integration of multiple sensory signals that activate or deactivate food search behaviors. Behaviors related to feelings of hunger or satiety are driven by the action of hormones and neurotransmitters ${ }^{9}$.

The molecule nNOS is found in the CNS and represents one of the three isoforms of NOS (neuronal [nNOS], inducible [iNOS], and endothelial [eNOS]), which is responsible for NO production using L-arginine as the substrate ${ }^{10}$. It is specifically found in the cytosol of neurons, has been implicated in a number of physiological functions in the brain such as synaptic plasticity, neurotransmission, and memory ${ }^{11-12}$ and directly participates in food control mechanisms ${ }^{13}$.

NO has been recognized as an important messenger molecule in cell signaling mechanisms in the CNS ${ }^{10}$ influencing towards increased levels of cyclic Guanosine Monophosphate (cGMP) after the activation of glutamate $\mathrm{N}$-methyl-D-aspartate receptors ${ }^{13}$. Studies have demonstrated the involvement of NO in hormones and peptides regulation including leptin, Neuro Peptide Y (NPY), orexin, and ghrelin ${ }^{14-16}$. This study reported that the inhibition of NO synthesis, via NOS, produces anorectic effects in slim and obese mice suggesting the participation of NO in feeding control.

Recent studies reinforced the theory that NO acts as a central mediator in food intake ${ }^{1,2}$ suggesting that its participation somehow acts regulating anorectic and orexigenic peptides. However, the mechanism involved in these findings is still unclear 12,17

Thus, this study evaluated changes in satiety after chronic oral supplementation of L-arginine, and the effects of acute L-arginine infusion in the hypothalamus on biochemical, behavioral, and anthropometric variables.

\section{METHODS}

This study was submitted and approved by the Animal Research Ethics Committee of Universidade Estadual do Centro-Oeste under Protocol n 026/2012.

The study used 20 male Wistar rats aged 60 days. Two to three animals were housed per cage in a quiet room with a 12:12 light/dark cycle and controlled temperature $\left(26 \pm 1^{\circ} \mathrm{C}\right)$. The animals had free access to food (Nutrivital ${ }^{\circledR}$ Chow) and filtered water during the experiments.

The animals were divided into two groups of 10 animals each: control and L-arginine. One milliliter and $2 \mu \mathrm{l}$ of saline $(0.9 \% \mathrm{NaCl})$ were administered by gavage and through the hypothalamic route to control animals, respectively. L-arginine (1 $\mathrm{g} / \mathrm{kg}$ of body weight) and $0.5 \mathrm{mM}$ $(2 \mu \mathrm{l})$ were administered by gavage and through the hypothalamic route to the L-arginine group, respectively. The doses used in this study have been used in other studies, were considered safe, and produced high concentrations of byproducts from the NO metabolism when injected in the brain $^{18-20}$.

\section{Gavage, food, and water control}

The animals were treated daily and orally (gavage) for 60 days, always at 1 pm. Daily feed and water consumption was evaluated, always at $1 \mathrm{pm}$, by measuring the difference between the initial and final measurements of feed and water within 24 hours of free access. 


\section{Stereotactic biopsy}

After eight weeks of L-arginine oral supplementation, the animals underwent a stereotactic microsurgery for the implantation of a guiding cannula to enable the administration of L-arginine or saline through microinfusion in the hypothalamus.

The animals were anesthetized intraperitoneally with a mixture of xylazine hydrochloride (5 to $10 \mathrm{mg} / \mathrm{kg}$ ) and ketamine hydrochloride (50 to $75 \mathrm{mg} / \mathrm{kg}$ ). Anesthetized animals were placed in a stereotactic apparatus (Insight ${ }^{\circledR}$ ETX3/99 model, Ribeirão Preto, Brazil) for the unilateral insertion of the cannula in the hypothalamus following the bregma coordinates: Anteroposterior (A/P): $1.0 \mathrm{~mm}$; Lateral (L): 0.5 $\mathrm{mm}$; and Ventral (V): $8.0 \mathrm{~mm}^{21}$. The cannula was secured with acrylic resin. Chloramphenicol (200 $\mathrm{mg} / \mathrm{kg}$, intraperitoneally) was administered immediately after the surgical procedure.

\section{Micro-infusion and behavioral evaluation}

Micro-infusion was initiated at least 72 hours after surgery and 96 hours after oral treatment with $2 \mu \mathrm{l}$ of L-arginine $(0.5 \mathrm{mM})$ or saline $(\mathrm{NaCl} 0.9 \%)$ in the hypothalamus of animals in the treatment and control groups, respectively and considering the time taken by the brain to absorb the solution (approximately 1 minute), at $1 \mathrm{pm}$. This procedure was performed one time to evaluate the effect of acute L-arginine administration on the central regulation of feed intake.

Animals were transferred to a round open field $(54.7 \mathrm{~cm}$ in diameter, divided in 12 quadrants) immediately after infusions. Animals were observed for the presentation of clonic or tonic convulsions during the 15 minutes open field session. The number of convulsive episodes and total time spent in convulsive behavior were recorded. A new convulsive episode was counted if the animal spent at least 10 seconds without behavioral manifestations and clonic movements restarted. Convulsive behavior was evaluated based on rotation of the body around its central axis, clonic or tonic contractions of the front or back paws freezing, tail and hind limb extension, forepaw dystonia, agitation, sniffing, squinting, mastication, facial clonus, crossing, rising, cleaning, and defecating.

Animals were individually housed in metabolic cages after the behavioral evaluation and hippocampal infusion; feed and water intakes were measured.

\section{Biochemical analyses}

The animals fasted for 12 hours before euthanasia; $5 \mathrm{~mL}$ of blood samples were collected and stored in tubes containing fluoride for glucose analysis, and in tubes without coagulant for glycerol and cholesterol analysis. Samples were centrifuged at $1500 \mathrm{rpm}$ for 10 minutes; serum samples were collected and analyzed in a biochemical analyzer (DIAGLOBE CA-2006 ${ }^{\circledR}$ ) for glucose, cholesterol, and glycerol dosing using a BioSystems kit.

\section{Body}

The animals were weighed weekly for the evaluation of weight gain. Some of the vital organs (kidneys, liver, adrenal glands, and brain) were removed after euthanasia for weight measurements in a precision scale (Shimadzu, São Paulo, Brazil).

\section{Histopathological analysis}

The removed vital organs were fixed in $10 \%$ formaldehyde for 48 hours, sectioned, and stained with Hematoxylin-Eosin (HE).

Variability in body weight and in feed and water intake during treatments (micro-infusion) were evaluated by Analysis of Variance (Anova) and the post hoc Tukey's test $(p<0.05)$. Metabolic 
variables, fat mass, Lee index, and post-treatment chow and water intake (gavage) between groups were evaluated by the Student's $t$ test $(p<0.05)$.

\section{RE S U L T S}

A mild increase in weight was observed during treatments (Figure 1); however, a significant increase in total body mass (3\%) was observed beginning on the sixth week of treatment in the group treated with $L$-arginine $\left[F_{(1.4)}=47.9\right.$; $p<0.001]$.

The oral administration of L-arginine reflected in increases in water intake $\left[\mathrm{t}_{(1.4)}=2.565\right.$; $p<0.05$ ] (Table 1). Table 2 shows the result of the studied biochemical parameters (cholesterol, glycerol, and glucose) after oral administration of L-arginine during 60 days; no statistically significant differences were observed. The organs were weighed at the end of the 60 days of treatment and after L-arginine micro-infusion. A statistically significant reduction was only observed in the total weight of the brain as the result of L-arginine administration (7\%) $\left[t_{(1.4)}=1.390 ; p<0.05\right.$ ] (Table 3). No convulsive behavioral changes were observed after $\mathrm{L}$-arginine

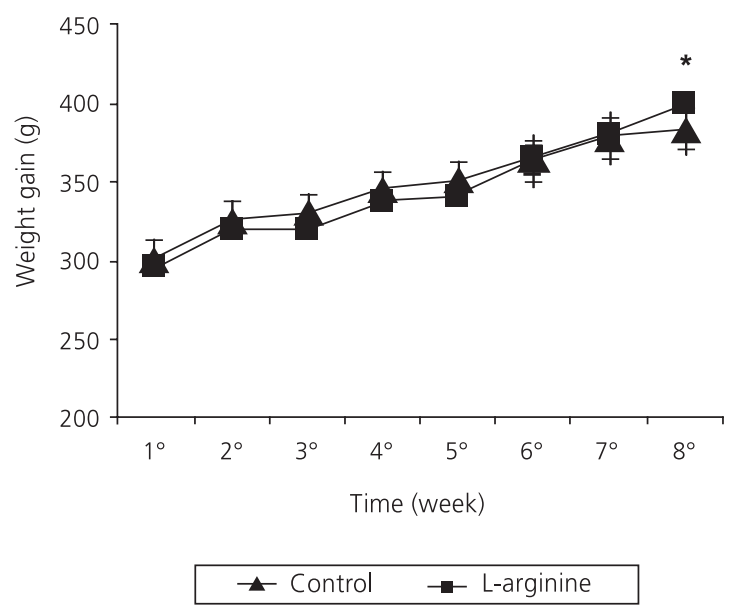

Figure 1. Weight gain evolution in Wistar male rats (in grams) according to total experimental time (in weeks) of oral administration in the control (saline) and treatment (L-arginine) groups ( $\mathrm{n}=10$ per group).

Note: " $p<0.05$; Student-Newman-Keuls after one-way analysis of variance.

micro-infusion, therefore, it was considered that this infusion does not alter brain function. Figure 2 shows the results from feed and water intake after L-arginine or saline infusion indicating that an important and significant increase was only observed in chow intake (30\%) after 24 hours from $L$-arginine administration $\left[F_{(1.14)}=9.9\right.$;

Table 1. Effect of L-arginine or saline (controls) oral administration on feed and water intake post 60 days of treatment $(n=10$ per group).

\begin{tabular}{lcccc}
\hline Variables & Control & L-arginine & $\%$ & $p$ \\
\hline Feed $(\mathrm{g})$ & $20.0 \pm 2.1$ & $21.8 \pm 2.0$ & 3 & 0.650 \\
Water $(\mathrm{mL})$ & $77.0 \pm 6.0$ & $44.0 \pm 8.0^{*}$ & 43 & 0.0001 \\
\hline
\end{tabular}

Note: *Statistically significant values only for $<p 0.05$

The values are presented as mean \pm standard deviation ( $n=10$ per group).

Table 2. Effect of oral L-arginine administration on plasma cholesterol, glycerol, and glucose levels in rats after 60 days of treatment.

\begin{tabular}{lcccc}
\hline Variables & Control & L-arginine & $\%$ & $p$ \\
\hline Cholesterol $(\mathrm{mg} / \mathrm{dL})$ & $173.0 \pm 4.3$ & $165.0 \pm 5.5$ & 6 & 0.594 \\
Glycerol $(\mathrm{mg} / \mathrm{dL})$ & $105.0 \pm 25.0$ & $140.0 \pm 32.0$ & 25 & 0.710 \\
Glucose $(\mathrm{mg} / \mathrm{dL})$ & $88.0 \pm 20.0$ & $84.0 \pm 16.0$ & 5 & 0.202 \\
\hline
\end{tabular}

Note: The values are presented as mean \pm standard deviation $(p<0.05)(n=10$ per group). 
Table 3. Effect of oral L-arginine administration on weight of different organs from rats after 60 days of treatment.

\begin{tabular}{|c|c|c|c|c|}
\hline \multirow{2}{*}{ Organs } & \multicolumn{2}{|c|}{ Weight (g/100 g of body weight) } & \multirow{2}{*}{$\%$} & \multirow{2}{*}{$p$} \\
\hline & Control & L-arginine & & \\
\hline Fat & $9.4 \pm 3.9$ & $7.2 \pm 1.5$ & 30 & 0.239 \\
\hline Brain & $1.9 \pm 0.03$ & $1.8 \pm 0.1^{*}$ & 5 & 0.026 \\
\hline Liver & $10.2 \pm 1.5$ & $10.6 \pm 1.9$ & 4 & 0.570 \\
\hline Heart & $1.6 \pm 0.19$ & $1.5 \pm 0.2$ & 6 & 0.735 \\
\hline Kidneys & $1.2 \pm 1.4$ & $1.3 \pm 0.2$ & 8 & 0.715 \\
\hline Adrenal glands & $0.04 \pm 0.01$ & $0.03 \pm 0.01$ & 33 & 0.662 \\
\hline
\end{tabular}

Note: The values are presented as mean \pm standard deviation $(p<0.05)(n=10$, per group).

*Significant difference compared with the control group only for $<p 0.05$.

A

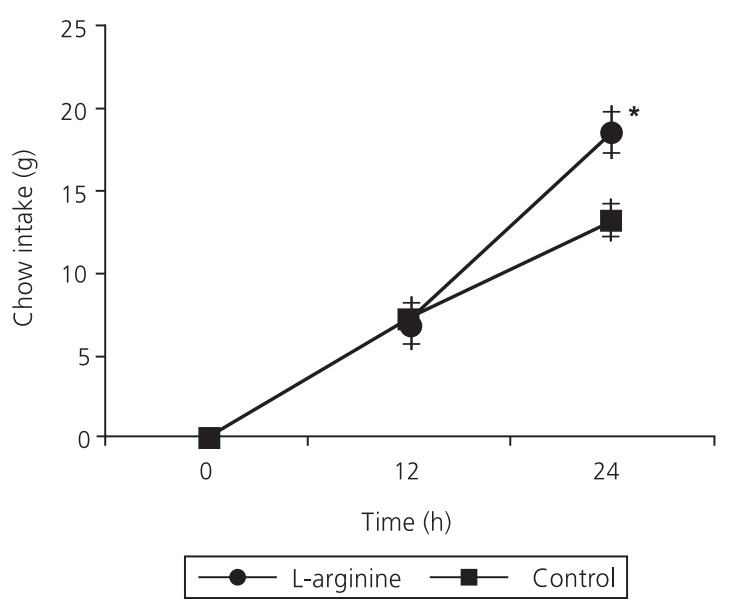

B

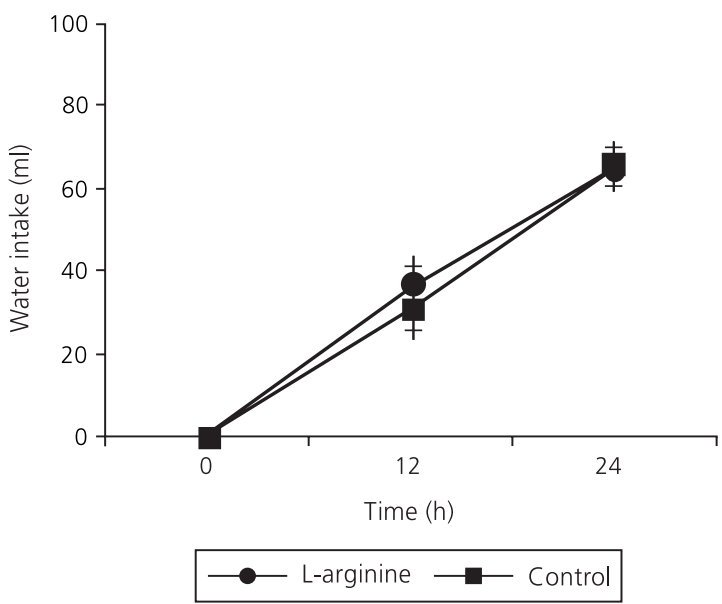

Figure 2. Feed intake (A) and water intake (B) after 12 and $24 \mathrm{~h}$ from L-arginine administration in the hypothalamus.

Note: The values are presented as mean \pm standard deviation $(p<0.05)$ ( $n=10$ per group).

*Significant difference compared to the control group for the same administration time only ( $p<0.05$; Student-Newman-Keuls after oneway analysis of variance). $p<0.005]$. Histopathological analysis of different organs (kidney, liver, adrenal gland and brain) did not detect changes in both the control group and the treatment-with-L-arginine group. In these slides we can see that there are no signs of cellular differentiation, inflammation, or edema.

\section{DISCUSSION}

In this study, a concentration of $0.5 \mathrm{mM}$ L-arginine was injected in the hypothalamus of rats, according to the methodology described by Tseng et al. ${ }^{19}$; a $25 \%$ increase in the concentration of nitrite and nitrate (by-products of the NO metabolism) was observed when L-arginine was injected in the brain, and around a 70\% increase of nitrite and nitrate was observed in blood samples, when L-arginine was administered orally ${ }^{21}$. L-arginine hypothalamic infusion promoted significant changes in satiety (Figure 2) that was quantified by the increased food intake after 24 hours from the L-arginine administration. This increase is probably related to a cascade of mediated signals via NO production.

The involvement of NO in feeding behavior, through the hypothalamus, has been confirmed in recent years by various studies ${ }^{1,10,15}$. Its action is related to different peptides with orexigenic action such as ghrelin, NPY, and orexin- $\mathrm{A}^{22}$. In addition, another study showed that NO has an important role on anorectic effects mediated by leptin?'. 
The effects of leptin modulating satiety are directly related to NO production. A decrease in food consumption induced by leptin infusion was mitigated by L-arginine infusion in chicken ${ }^{23}$. Ventricular intra-brain infusions of leptin promoted an expected suppression of food intake and reduction in nNOS activity; both effects are antagonized by L-arginine infusions ${ }^{1}$.

Conversely, the oral and chronic L-arginine treatments did not reflect in statistically significant differences regarding feed intake. The modulation of satiety has been discussed based on NO formation via nNOS in different studies ${ }^{15,24}$. Thus, when orally administered, L-arginine could follow different paths, from the digestive tract to other metabolic pathways in various tissues, where NO formation could display a myriad of other functions, other than modulation of satiety ${ }^{15}$. In addition, the orexigenic effect provided by the oral supplementation with L-arginine probably occurs in a time-dependent way. Future studies with a serial analysis at different time points to assess food intake after oral supplementation could confirm this result.

Recently, Prodam et al. ${ }^{2}$ prescribed acute intravenous L-arginine $(0.5 \mathrm{~g} / \mathrm{kg}$ infusion iv, maximum of $30 \mathrm{~g}$ within 30 minutes) to prepubescent children divided into sufficient growth hormone (GH) secretion and insufficient $\mathrm{GH}$ secretion and did not observe significant changes in the ghrelin orexigenic hormone after 30 minutes of $\mathrm{L}$-arginine infusion. However, after 120 minutes, a marked increase in relation to the 30 minute infusion was observed ( 250 to $400 \mathrm{pg} / \mathrm{mL}$ ). This increase occurs independently of $\mathrm{GH}$ levels and no difference between the groups with and without abnormal $\mathrm{GH}$ secretion was observed. Thus, the intravenous infusion of L-arginine $(0.5 \mathrm{~g} / \mathrm{kg})$, even at doses lower than those used in the oral supplementation in this study $(1 \mathrm{~g} / \mathrm{kg})$, results in better effects on the regulation of satiety in a time-dependent way with noticeable effects after 60 to 120 minutes of infusion; times superior to 120 minutes were not monitored. In the present study, food intake was monitored daily at the same time after 24 hours of oral L-arginine supplementation.
However, the orexigenic effect of L-arginine could be occurring in the early hours after the supplementation.

In addition, an increase in the absolute weight was observed in animals treated with L-arginine orally and chronically, which correlates with increased water intake that fits with ratios between total body mass and water replacement needs. Previous studies showed that L-arginine may act on two fronts in these events, one goes through an amplified signal for the production of $\mathrm{GH}$ via stimulus in the anterior hypophysis ${ }^{25}$, and the other through an alternate route in the process of creatine formation and consequently resulting in a sarcoplasmic hypertrophy from increased fluid retention ${ }^{26}$ and increased contractile filaments ${ }^{23}$.

Conversely, the D-arginine stereoisomer does not influence the appetite suppressant effect caused by leptin and subsequent body weight gain, which are effects that exclude the possibility of a non-specific effect on feeding behavior via NO formation ${ }^{17}$.

\section{CONCLUSION}

There is strong evidence on the involvement of $\mathrm{NO}$ in the control of satiety. Interestingly, this study shows that chronic oral treatment with L-arginine, even if in a dose representative for NO stimulation, does not guarantee strong effects on appetite modulation. This effect was only achieved when L-arginine was administered directly into the hypothalamus. Chronic oral administration of L-arginine did not reflect considerable changes in the biochemical and behavioral (feed intake) changes. To the extent that this study reinforces the importance of L-arginine in the modulation of chow intake when administered in the hypothalamic route, future studies should investigate the effect of this supplementation in different doses, different sites, evaluating food ingestion at different time points, and using different NOS isoforms to assess correlations between chow intake and oral and chronic administration of L-arginine. 


\section{A C KNOWLEDGEMENTS}

The authors are thankful to Coordenação de Aperfeiçoamento de Pessoal de Nivel Superior and Fundação Araucaria Paraná for the financial support to this study.

In memoriam to professor John Lang Pavlak for their dedication in the master's degree in Pharmaceutical Sciences - Universidade Estadual do Centro-Oeste.

\section{O NTRIBUTORS}

CRM MALFATTI performed the statistical analyses, created and interpreted the graphs, wrote the manuscript, and discussed the results; LA SILVA collected data, searched the literature, performed the statistical analyses, created and interpreted the graphs, wrote the manuscript, and discussed the results; RA PEREIRA collected data and wrote the manuscript; RG MICHEL collected data and searched the literature; AL SNAK wrote the manuscript and discussed the results. FS SANTOS wrote the manuscript and discussed the results.

\section{REFERE NCES}

1. Mancuso C, Navarra P, Preziosi P. Roles of nitric oxide, carbon monoxide, and hydrogen sulfide in the regulation of the hypothalamic-pituitaryadrenal axis. J Neurochemist. 2010; 113(3):563-75.

2. Prodam F, Genoni G, Bellone S, Longhi S, Agarla V, Bona $\mathrm{G}$, et al. Effect of arginine infusion on ghrelin secretion in growth hormone sufficient and $\mathrm{GH}$ deficient children. Int J Endocrinol Metab. 2012; 10(2):470-4.

3. Salunke BP, Umathe SN, Chavan JG. Experimental evidence for involvement of nitric oxide in low frequency magnetic field induced obsessive compulsive disorder-like behavior. Pharmacol Biochem Behav. 2014; 122(1):273-8.

4. Morris Junior SM. Arginine: Beyond protein. Am J Clin Nutr. 2006; 83(2):508-12.

5. Haase L, Green E, Murphy C. Males and females show differential brain activation to taste when hungry and sated in gustatory and reward areas. Appetite. 2011; 57(2):421-34.

6. Lalitha $V$, Pal G, Parija S, Pal P, Sathishbabu M, Indumathy J. Effect of gender on food intake, adiposity and immunological responses following lesion of ventromedial hypothalamus in albino Wistar rats. Int J Clin Exp Physiol. 2014; 1(1):41-4.

7. Matarese G, Procaccini C, Menale C, Kim JG, Kim JD, Diano S, et al. Hunger-promoting hypothalamic neurons modulate effector and regulatory T-cell responses. Proc Nat Acad Sci. 2013; 110(15):6193-8.

8. Melega WP, Lacan G, Gorgulho AA, Behnke EJ, De Salles AAF. Hypothalamic deep brain stimulation reduces weight gain in an obesity-animal model. PLOS ONE. 2012; 7(1):e30672.

9. Borges BC, Antunes-Rodrigues J, Castro M, Bittencourt JC, Elias CF, Elias LL. Expression of hypothalamic neuropeptides and the desensitization of pituitary-adrenal axis and hypophagia in the endotoxin tolerance. Horm Behav. 2007; 52(4):508-19.

10. Sadler CJ, Wilding JPH. Reduced ventromedial hypothalamic neuronal nitric oxide synthase and increased sensitivity to NOS inhibition in dietary obese rats: Further evidence of a role for nitric oxide in the regulation of energy balance. Brain Res. 2004; 1016(2):222-8.

11. Tamagnini F, Barker G, Warburton EC, Burattini C, Aicardi G, Bashir Zl. Nitric oxide-dependent longterm depression but not endocannabinoidmediated long-term potentiation is crucial for visual recognition memory. J Physiol. 2013; 591(Pt 16):3963-79.

12. Morley JE, Farr SA, Sell RL, Hileman SM, Banks WA. Nitric oxide is a central component in neuropeptide regulation of appetite. Peptides. 2011; 32(4):776-80.

13. Marcoli M, Cervetto C, Paluzzi P, Guarnieri S, Raiteri M, Maura G. Nitric oxide-evoked glutamate release and cGMP production in cerebellar slices: Control by presynaptic 5-HT1D receptors. Neurochem Int. 2006; 49(1):12-9.

14. Leshan RL, Greenwald-Yarnell M, Patterson CM, Gonzalez IE, Myers MG. Leptin action through hypothalamic nitric oxide synthase-1-expressing neurons controls energy balance. Nat Med. 2012; 18(5):820-3.

15. Wei T, Zhao X, Hou J, Ogata K, Sakaue T, Mori A, et al. The antioxidant ESeroS-GS inhibits NO production and prevents oxidative stress in astrocytes. Biochem Pharmacol. 2003; 66(1):83-91.

16. Selcher JC, Xu W, Hanson JE, Malenka RC, Madison DV. Glutamate receptor subunit GluA1 is necessary for long-term potentiation and synapse unsilencing, but not long-term depression in mouse hippocampus. Brain Res. 2012; 1435(0):8-14.

17. Kalra SP, Kalra PS. NPY and cohorts in regulating appetite, obesity and metabolic syndrome: 
Beneficial effects of gene therapy. Neuropeptides. 2004; 38(4):201-11.

18. Paxinos G, Watson C. The rat in stereotaxic coordinates. San Diego: Academic Press; 1986.

19. Tseng LF, Xu JY, Pieper GM. Increase of nitric oxide production by L-arginine potentiates i.c.v, administered l-endorphin-induced antinociception in the mouse. Eur J Pharmacol. 1992; 3(2-3); 212:301-3.

20. Xue J-J, Liu H-Y. Effects of intracerebroventricular microinjection of L-arginine on exercise capacity and expression of nitric oxide in rat hypothalamus. Zhongguo Ying Yong Sheng Li Xue Za Zhi. 2013; 29(2):158-61.

21. Lima JM, Silva AS, Alves NF, Porpino SK. L-Arginine increases endothelial nitric oxide production and reduces blood pressure of rest without changing the exercise pressor response. Motricidade. 2012; 8(3):19-29.

22. Farr SA, Banks WA, Kumar VB, Morley J. Orexin-A induced feeding is dependent on nitric oxide. Peptides. 2005; 26(5):759-65.
23. Weltman A, Pritzlaff CJ, Wideman L, Weltman JY, Blumer JL, Abbott RD, et al. Exercise-dependent growth hormone release is linked to markers of heightened central adrenergic outflow. J Appl Physiol. 2000; 89(2):629-35.

24. Gentilcore D, Visvanathan R, Russo A, Chaikomin $R$, Stevens JE, Wishart JM, et al. Role of nitric oxide mechanisms in gastric emptying of, and the blood pressure and glycemic responses to, oral glucose in healthy older subjects. Am J Physiol Gastrointest Liver. 2005; 288(6):1227-32.

25. Collier SR, Casey DP, Kanaley JA. Growth hormone responses to varying doses of oral arginine. Growth Horm. 2005; 15(2):136-9.

26. Yang SJ, Denbow DM. Interaction of leptin and nitric oxide on food intake in broilers and Leghorns. Physiol Behav. 2007; 92(4):651-7.

Receveid: May 16, 2014

Final version: October 3, 2014

Approved: October 23, 2014 
